\title{
REACTIVE OXYGEN SPECIES IN THE PATHOGENESIS OF STRESS-INDUCED GASTRIC ULCERATION IN RATS AND PROTECTIVE EFFECT OF OMEPRAZOLE
}

\author{
J. DOUBEK ${ }^{1}$, P. SVOBODA ${ }^{2}$, A. LOJEK $^{3}$, I. KANTOROVÁ ${ }^{2}$, M. CÍZ Ż ${ }^{3}$. E. ČERNÁ ${ }^{1}$ \\ ${ }^{1}$ Department of Pathophysiology, University of Veterinary and Pharmaceutical Sciences, Brno \\ ${ }^{2}$ UN - Research Centre for Traumatology and Surgery of Czech Ministry of Health, Brno \\ ${ }^{3}$ Institute of Biophysics, Academy of Sciences of the Czech Republic. Brno
}

Received April 9, 1996

Accepted September 24, 1996

\begin{abstract}
Doubek J., P. Svoboda, A. Lojek, I. Kantorová, M. Cíž, E. Cerná: Reactive Oxygen Species in the Pathogenesis of Stress-Induced Gastric Ulceration in Rats and Protective Effect of Omeprazole. Acta vet. Brno 1996, 65:201-207.

To examine the role of reactive oxygen species (ROS) in stress-induced gastric ulceration and possible protective effect of proton pump inhibitor omeprazole male adult rats were immobilized for 9 hours. Phagocyte-derived ROS were measured using the chemiluminescence method in whole blood obtained at start and after 3,6 , and 9 hours of immobilization. As indirect sign of gastric mucosal damage faeces were examined after 3 and 6 hours for blood spots presence and after 9 hours the animals were killed and stomachs were examined.

Stress resulted in a gigantic increase of ROS in immobilized animals both without and with omeprazole. Blood spots were not found after 3 hours of immobilization. After 6 hours, massive presence of blood spots was found in immobilized animals in contrast to minimal presence $(\mathrm{P}<0.001)$ in rats treated with omeprazole. The same difference was observed for macroscopically evaluated gastric mucosa after decapitation.

We conclude that immobilization causes a large increase of ROS in rats and this increase is not influenced by omeprazole. In contrast, omeprazole decreased bleeding from gastric mucosa and dramatically decreased both number and severity of gastric mucosal lesions.
\end{abstract}

Rat, reactive oxygen species, immobilization, gastric ulcer, omeprazole.

Various physical and psychological stresses cause gastric ulceration in humans and animals. The exact pathogenesis of ulcer generation still remains unclear. Various mechanisms like decreased gastric mucosal blood flow (Kitag aw a et al. 1979), increased gastric motility ( G a r r i c k et al. 1986), acetylcholine as a mediator of vagal hyperactivity ( Gat on et al. 1993), decreased prostaglandin serum (Mille r 1987) or mucosa level (Gitlin et al. 1988), and increased vascular permeability (Takeuchi et al. 1991) are supposed to be involved in ulcer development. Recently, attention has been focused on the role of reactive oxygen species (ROS). ROS have been found to play a role in experimental gastric damage induced by immobilization (Mancinelli et al. 1990), hemorrhagic shock ( I to h and Guth, 1985), reperfusion ( Perry et al. 1986), and nonsteroidal antiinflammatory drugs (Takeuchi et al. 1991). It is assumed that the gastric damage in rats induced by immobilization stress may have a pathogenic mechanism in common with other types of stress. Multiple organ failure (MOF) is the leading cause of late postinjury death in humans as in animals. The stress ulcer generation in MOF is mostly fatal.

The purpose of the study presented here therefore was to study the effect of immobilization stress on the reactive oxygen species production during the development of gastric ulceration and to correlate these changes with a possible protective effect of the $\mathrm{H}^{+}$ion blocker omeprazole on gastric ulceration. Omeprazole 
is assumed to be the highly selective specific dose-dependent inhibitor of the $\mathrm{H}^{+}, \mathrm{K}^{+}$ATPase (proton pump) in the parietal cell.

\section{Materials and Methods}

Male Wistar rats (Institute of Biophysics, Academy of Sciences of the Czech Republic, Brno) weighing 350-450g were used throughout all experiments. The animals were kept in cages made of transparent polypropylen under controlled temperature and light, and food and water were given ad libitum. The adaptation time for each experiment was 14 days.

\section{General Protocols}

The study was approved by the Scientific and Ethic Committee of Research Center for Traumatology and Surgery of Czech Ministry of Health and by the Ethic Committee Veterinary Faculty of University of Veterinary and Pharmaceutical Sciences in Brno.

All studies were carried out using 6-10 rats per group. Three groups of rats were evaluated. The animals were fasted but allowed free access to water for 8 hours prior to the experiment and kept at room temperature. A small polyethylene catheter was introduced by puncture of the tail vein 60 minutes before start of the experiment. Blood samples $(10 \mu \mathrm{l})$ for laboratory examination were obtained from tail vein immediately before the immobilization, then 3 and 6 hours after the immobilization. The animals were killed under deep ether anaesthesia by decapitation after 9 hours and last blood samples were obtained from cut neck arteries and veins.

To induce the stress ulcer, the experimental rats were immobilized in the transparent cylinder with respiratory openings - group $A$.

In 6 rats the immobilization was performed in the same way as in group A, but a large dose of $1 \mathrm{mg} / \mathrm{kg}$ body mass of omeprazole (Losec, Astra, Södertälje, Sweden) was administered to each animal as a water suspension by metal probe immediately after immobilization - group B.

A group kept under these conditions without immobilization has been included as group $\mathrm{C}$ (control group) to eliminate possible influence of the described protocol on investigated parameters.

\section{Evaluation of mucosal bleeding, ulcer index}

As an indirect sign of ulcer generation, faeces were investigated 3 and 6 hours after immobilization for blood spot presence by modified guaiak test Haemoccult (Röhm Pharma, Weiperstadt, Germany) and semiquantitatively evaluated. The person evaluating the samples did not know the treatment protocol. Samples without blood spots presence were assessed 0 (no colour change), minimal blood presence 1 (grey), medium 2 (grey-blue), and samples with maximal presence to 3 (Victoria blue) of the 4 degree scale. The sum of total scores in both stress exposed groups divided by the number of animals was expressed as the mean bleeding index.

After decapitation the stomachs were removed, inflated by $8 \mathrm{ml}$ of $2 \%$ formalin, immersed in $2 \%$ formalin for gastric wall fixing, and the mucosa was exposed by cutting along the greater curvature. The incidence of gastric ulcers was examined with the help of a magnifying glass by an examiner having no knowledge of treatment regime. The length of each lesion in millimetres was summed per stomach and used as ulcer index. The precise differentiation between mucosal lesion and ulcer was not done assuming the fact that these are two phases of the same process.

\section{Determination of reactive oxygen species}

A stock solution of $10 \mathrm{mM}$ luminol (5-amino-2,3-dihydro-1,4 phtalazinedione, Sigma, USA) was prepared in $0.2 \mathrm{M}$ sodium borate puffer with pH 9.0. Hanks's balanced salt solution (HBSS) without phenol red ( $\mathrm{pH}$ 7.4). Zymosan (zymosan A from Saccharomyces cerevisiae, Sigma, USA) $180 \mathrm{mg}$ was boiled in $9 \mathrm{ml}$ of phosphate buffer $(\mathrm{pH} \mathrm{7.6)}$ and washed three times in HBSS. For opsonization the suspension was incubated in $65 \%$ rat serum at $37{ }^{\circ} \mathrm{C}$ for 60 minutes and washed twice with HBSS. Opsonized zymosan was resuspended $(20 \mathrm{mg} / \mathrm{ml})$ in HBSS containing $0.1 \%$ gelatine. The suspensions were stored at $-70^{\circ} \mathrm{C}$.

Production of phagocyte-derived reactive oxygen species was measured using the chemiluminescence (CL) method in whole blood diluted in HBSS buffer (10 $\mathrm{ml}$ whole blood:1990 ml HBSS). The experiments were performed at $37^{\circ} \mathrm{C}$ using $300 \mathrm{ml}$ of blood suspension as mentioned above, $50 \mathrm{ml}$ of luminol in final concentration of $1.4 \times 10^{-4} \mathrm{M}$ and $50 \mathrm{ml}$ of opsonized zymosan per cuvette. The assays were run with three repeats. CL emission was measured with BioOrbit (Finland) luminometer LKB 1251. The measurements of $\mathrm{CL}$ emission were repeated at 201 second intervals for 60 minutes to obtain kinetic curves. For the intensity of ROS production of the sample, the peak CL and integral of the 60 minute curve was used. 
Statistics

Data are presented as mean \pm SEM (standard error of the mean). Significance was calculated from paired and unpaired Student's t-test.

\section{Results}

For the samples obtained 3 hours after exposure of rats to immobilization stress, no presence of blood in faeces was observed in any of the animals. After 6 hours the positive Haemoccult test was found in all animals from group A with bleeding index $2.3 \pm 0.3$, while only 1 rat $(17 \%)$ of group B treated with omeprazole had a minimally positive test; bleeding index of group $B$ was $0.2 \pm 0.2(\mathrm{P}<0.001)$. No blood-trace was found in control group $\mathrm{C}$.

Exposure of rats to immobilization stress for 9 hours induced severe hemorrhagic gastric lesions/ulcers in all animals of group A with ulcer index 5.9 \pm 1.0 . In group B 3 rats developed a small lesion and 3 remained without lesions with ulcer index $0.9 \pm 0.2$ $(\mathrm{P}<0.001)$. No ulcer was observed in control group (Table 1).

While studying the role played by reactive oxygen species on the stress-induced gastric damage, production of phagocyte-derived reactive oxygen species was measured. The curves representing the kinetics of ROS production measured as CL activity for 60 minutes are shown in Figs 1 and 2 (groups A and B) Group C is not

Table 1

\section{Bleeding index and ulcer index (Mean \pm SEM)}

Bleeding index

Ulcer index

3 hours

6 hours

9 hours

Group A $(n=10)$

(immobilization)

Group B $(n=6)$

(immob. + omepr.)

Group C $(n=7)$

(control)

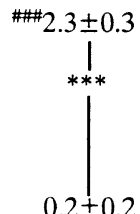

0

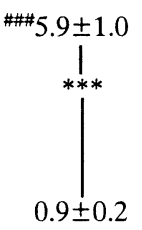

0

\# indicates values that are significantly (\#\# $\mathrm{P}<0.001$ ) different from the baseline value for the same group, * indicates values that are significantly $(* * * \mathrm{P}<0.001)$ different between the groups. Control group has not been evaluated statistically.

shown, all curves of group C are similar to „start“ curve of groups A and B. The peak levels and integrals in the control group remained significantly unchanged during 9 hours of the experiment. In group A starting CL peak was $1.812 \pm 0.376 \mathrm{mV}$, integral $5287 \pm 1213 \mathrm{mV} . \mathrm{s} ;$ a non-significant increase after 3 hours (peak $2.973 \pm 0.414 \mathrm{mV}$, 


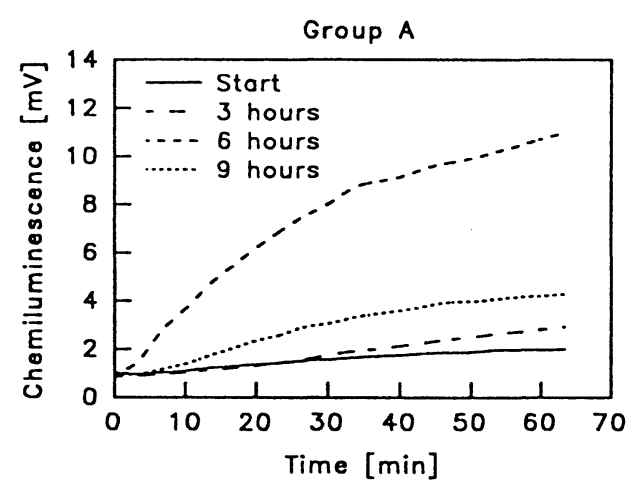

Fig. 1. Kinetics of $\mathrm{CL}$ response of whole-blood phagocytes activated with opsonized zymosan in different intervals after immobilization of animals (group A - without omeprazole treatment). The curves are constructed from 20 points; every point was obtained as an average value of 10 assays.

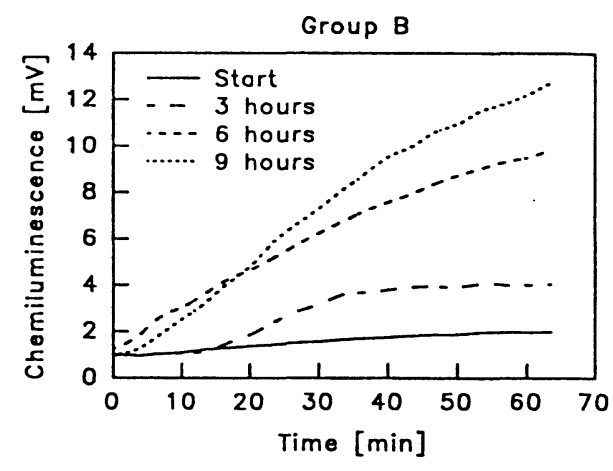

Fig. 2. Kinetics of CL response of whole-blood phagocytes activated with opsonized zymosan in different intervals after immobilization of animals (group B - with omeprazole treatment). The curves are constructed from 20 points; every point was obtained as an average value of 6 assays.

Table 2

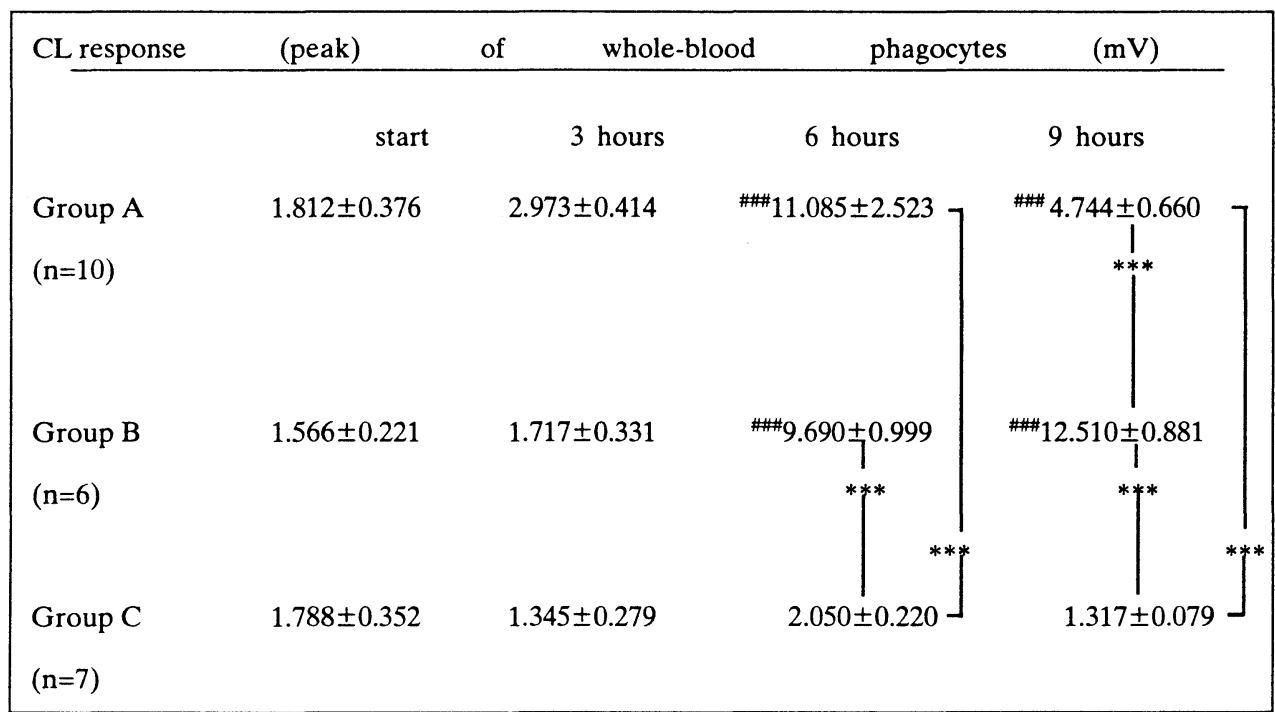

\# indicates values that are significantly (\#\# $\mathrm{P}<0.001$ ) different from the baseline value for the same group,

$*$ indicates values that are significantly $(* * * \mathrm{P}<0.001)$ different between the groups.

integral $7091 \pm 1809 \mathrm{mV} . \mathrm{s}$ ) was followed by a gigantic increase at 6 hours (peak $11.085 \pm 2.523 \mathrm{mV}$, integral $28086 \pm 6028 \mathrm{mV} . \mathrm{s}, \mathrm{P}<0.001$ ) and a smaller but still dramatic increase after decapitation (peak $4.744 \pm 0.660 \mathrm{mV}$, integral $12060 \pm 1490 \mathrm{mV} . \mathrm{s}, \mathrm{p}<0.001$ ). The values for group $\mathrm{B}$ treated with omeprazole rose slowly and culminated after 9 hours. The corresponding values for group B were 
starting peak $1.566 \pm 0.221 \mathrm{mV}$, integral $4990 \pm 695 \mathrm{mV} . \mathrm{s}$, peak $1.717 \pm 0.331 \mathrm{mV}$, integral 5008 $\pm 792 \mathrm{mV} . \mathrm{s}$, non-significant changes after 3 hours, peak $9.690 \pm 0.999 \mathrm{mV}$, integral $22803 \pm 2519 \mathrm{mV} . \mathrm{s}, \mathrm{P}<0.001$ after 6 hours, and peak $12.510 \pm 0.881 \mathrm{mV}$, integral 27547 $\pm 1922 \mathrm{mV} . \mathrm{s}, \quad \mathrm{P}<0.001$ after decapitation, respectively (Table 2, Figs. 3 and 4 ).

\section{Discussion}

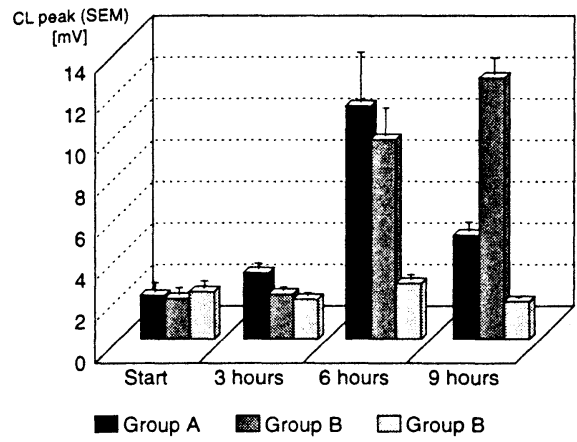

Fig. 3. CL response of whole-blood phagocytes activated with opsonized zymosan expressed as peak values (mean \pm SEM)

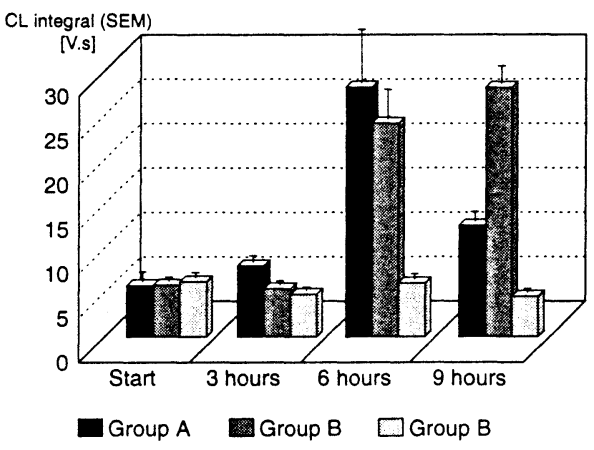

Fig. 4. CL response of whole-blood phagocytes activated with opsonized zymosan expressed as integral values (mean \pm SEM)

Although the aetiology of stress-induced gastric ulceration in rat has been studied by many investigators, the actual pathophysiology is still obscure. The involvement of $\mathrm{H}^{+}$, the commonly known damaging factor in the pathogenesis of mucosal injury, has been challenged as administration of antacids provided no protection against stress ulcer. The increased level of histamine during cold stress being activator of gastric acid output has been indicated to be responsible for the severe inflammation observed in the ulcerated stomach (Cho and Ogle 1992). On the contrary, D a s and B a n e r je e (1993) found significantly lower acid output during cold stress, what could be explain with some blocking effect of stress on parietal cell signal transduction or the terminal $\mathrm{H}^{+}, \mathrm{K}^{+}$-ATPase.

Besides the damaging effect of acid, the role of reactive oxygen species released by leukocytes as well as those derived from xanthine oxidase system may play an important role in the early stage of gastric lesions ( T a ke u ch i et al. 1991). ROS mediated lipid peroxidation increases membrane fluidity, permeability and loss of integrity and may thus be involved in gastric mucosal damage during stress (Freeman and Crapo 1982). Indomethacin interacted with ROS to cause severe mucosal injury after irradiation with hydroxyl free radicals, even at a nonulcerogenic dose (Del Soldato et al. 1985). On the other hand, B a n e r je e (1990) reported inhibited gastric peroxidase activity and increased accumulation of toxic oxygen metabolites in the gastric mucosa after nonsteroidal antiinflammatory drugs inhibit the gastric peroxidase activity.

To study the role of ROS in the pathogenesis of stress ulcer in rats and the possible protective effect of proton pump blocker omeprazole, we evaluated one of the most severe stresses, immobilization ( $\mathrm{Sudo}$ and Miki 1993). In our study, the ROS 
increased dramatically during stress both in the immobilized group without treatment and with omeprazole treatment; the increase in the omeprazole group was even greater. While a good correlation between ROS and bleeding index and ulcer index in immobilized group was found, in the omeprazole group the bleeding index was significantly lower and a small bleeding was observed in only one rat. The same difference - almost normal finding on gastric mucosa in contrast to the gigantic increase of ROS in omeprazole group when compared with many large ulcers in the simple immobilized group with similar ROS activity. We were able to prevent the bleeding from GIT in all animals except one. The gastric lesions after 9 hours of immobilization were significantly less frequent and smaller, when the animals were treated by omeprazole after immobilization. Omeprazole as a selective proton pump inhibitor inhibits the final stage of gastric acid formation. There is effective inhibition of both basal and stimulated acid secretion irrespective of the stimulus to acid formation. Omeprazole has no effect on acetylcholine or histamine receptors and no clinically significant pharmacodynamic effects have been observed other than those explained by the effect of omeprazole on acid secretion (Protzer and Holtermüller 1993). An important role of $\mathrm{H}^{+}$ions not directly related to $\mathrm{ROS}$ in the ulcer formation is suggested by our finding. In our opinion, omeprazole can be used preventively in conditions predisposed to MOF development in our patients. No protection for acute stress gastric ulcer of $\mathrm{H}_{2}$ receptor blocker ranitidin or aluminium hydroxide, but similar protection of allopurinol as in our study has been found by M a n cin elli et al. (1990).

In conclusion, our study suggests that immobilization causes a constant and a large increase of ROS in rats and this increase is not influenced by a potent $\mathrm{H}^{+}$ions blocker omeprazole. In contrast, omeprazole eradicated bleeding from gastric mucosa and dramatically decreased both number and severity of gastric mucosal lesions. The protective effect of preventive administration of omeprazole to patients with critical trauma or other life-threatening disease is assumed.

\section{Reaktivní formy kyslíku v patogenesi stresových vředů žaludku u potkana a protektivní účinek omeprazolu}

Byla zjištována úloha reaktivních forem kyslíku (ROS) při vzniku žaludečních ulcerací a potenciální protektivní účinek inhibitoru $\mathrm{H}^{+}, \mathrm{K}^{+}$-ATPasy omeprazolu u imobilizovaných dospělých potkanů samčího pohlaví.

Produkce ROS byla měřena metodou chemiluminiscence $v$ plné krvi v čase $0 \mathrm{~h}, 3$ $\mathrm{h}, 6 \mathrm{~h}$ a $9 \mathrm{~h}$ trvání experimentu. $\mathrm{V}$ čase $3 \mathrm{~h}$ a $6 \mathrm{~h}$ byl prováděn průkaz krve ve faeces a hodnocen index krvácení. Po $9 \mathrm{~h}$ byli potkani utraceni dekapitací v éterové anestezii a ze změn na žaludeční sliznici byl hodnocen index vředủ.

U imobilizovaných zvíŕat (bez omeprazolu i s omeprazolem) byl prokázán vzestup produkce ROS, při čemž v čase $6 \mathrm{~h}$ a $9 \mathrm{~h}$ byly rozdíly oproti neimobilizovaným zvíratům významné $(\mathrm{P}<0,001)$. Významné rozdíly $(\mathrm{P}<0,001)$ mezi imobilizovanými zvíraty bez omeprazolu a s omeprazolem byly zjištěny i v hodnotách indexu krvácení $\mathrm{v}$ čase $6 \mathrm{~h}$ a indexu ulcerací $\mathrm{v}$ čase $9 \mathrm{~h}$.

Z výsledků vyplývá, že imobilizační stres vedl u potkanů k významnému zvýšení produkce ROS. Omeprazol signifikantně snížil stupeň poškození sliznice žaludku, ale tvorbu ROS, jak bylo očekáváno, neovlivnil. Potvrzuje to, že ROS jsou jen jedním z ulcerogenních faktorů a zdrojem ROS za stresu není pouze poškození tkáně. 


\section{References}

BANERJEE, R. K. 1990: Nonsteroidal anti-inflammatory drugs inhibit gastric peroxidase activity. Biochim. Biophys. Acta 1034: 275-280

CHO, C. H., OGLE, C. W. 1992: The pharmacological differences and similarities between stress and ethanol induced gastric mucosal damage. Life Sci. 51: 1833-1842

DAS, D., BANERJEE, R. K. 1993: Effect of stress on the antioxidant enzymes and gastric ulceration. Mol. cell. Biochem. 125: 115-125

FREEMAN, B. A., CRAPO, J. D. 1982: Biology of disease. Free radicals and tissue injury. Lab. Invest. 47: $412-$ 426

GARRICK, T., BUACK, S., BASS, P. 1986: Gastric motility is a major factor in cold restraint induced lesion formation in rats. Am. J. Physiol. 250: G191-G199

GATON, J., GANDARA, F., VELASCO, A. 1993: The role of the neurotransmitters acetylcholine in the pathogenesis of stress ulcers. Comp. Biochem. Physiol. (C) 106: 125-129

GITLIN, N., GINN P., KOBAYASHI, K., ARAKAWA, T. 1988: The relationship between plasma cortisol and gastric mucosa prostaglandin levels in rats with stress ulcers. Aliment. Pharmacol. Ther. 2: 213-220

ITOH, M., GUTH, O. H. 1985: Role of oxygen derived radicals in hemorrhagic shock induced gastric lesions in the rat. Gastroenterology 88: 1162-1167

KITANAGAWA, H., FUJIWARA, M., OSUMI, Y. 1979: Effect of water immersion on gastric secretion and mucosal blood flow in rats. Gastroenterology 77: 298-302

MANCINELli, S. P., FUENTE, G. M. de la, MANRIQUEZ, V. F., ARACENA, M. F., MUÑOZ, R. F., MANCINELI, S. C., MUŇOZ, S. V. 1990: Etiopatogenia de la ulcera aguda por estres. Rol de los oxidantes derivados del oxigeno. Rev. Méd. Chile 118: 965-970

MILLER, T.A. 1987: Mechanisms of stress-related mucosal damage. Am. J. Med. 83: 8-14

PERRY, M. A., WADHAWA, S., PARKS, D. A., PICKARD, W., GRANGER, D. N. 1986: Role of oxygen radicals in ischemia-induced gastric lesion in the cat stomach. Gastroenterology 90: 362-367

PROTZER, U., HOLTERMÜLLER, K. H. 1993: Omeprazole. Pharmakologie und therapeutische Wirksamkeit. Dtsch. med. Wschr. 118: 230-239

SOLDATO, P. D. del, FOSCHI, D., BENORI, G., SCARPIGNATO, C. 1985: Oxygen free radicals interact with indomethacin to cause gastrointestinal injury. Agents Actions 17: 484-488

SUDO, A., MIKI, K. 1993: Dissociation of catecholamine and corticosterone responses to different types of stress in rats. Ind. Health 31: 101-111

TAKEUCHI, K., UESHIMA, K., HIRONAKA, Y., FUJIOKA, Y., MATSUMOTO, J., OKABE, S. 1991: Oxygen free radicals and lipid peroxidation in the pathogenesis of gastric mucosal lesions induced by indomethacin in rats. Digestion 49: 175-184

Address for correspondence:

MVDr. J. Doubek, CSc.

Department of Pathophysiology

University of Veterinary and Pharmaceutical Sciences

Palackého 1-3

CZ-612 42 Brno

Czech Republic 